\title{
Electrolyte Performance of Noni Fruit Extracts (Morinda Citrifolia L.) for C-Zn Batteries
}

\author{
Said Ali Akbar ${ }^{*}$, Dilla Armelianda, Muttakin \\ Department of Chemical Education, Serambi Mekkah University, 23245, Banda Aceh, Aceh, \\ Indonesia \\ *email: said.aliakbar@serambimekkah.ac.id
}

Received: 03/11/2018; Revised: 04/12/2018; Accepted: 04/12/2018

\begin{abstract}
$\mathrm{C}-\mathrm{Zn}$ battery is a commercial battery that widely used due to its easy to carry, inexpensive, and easy to obtain. However, the serious thing is the problem of battery waste which not only causes pollution but also endangers natural resources due to contained heavy metals (Mn) and corrosive electrolytes. Noni (Morinda Citrifolia L.) is a fruit with the main component of vitamin C (ascorbic acid) as an antioxidant. This acid component is the basis for further utilization as an environmentally friendly electrolyte application. Noni was fermented with 2 time variations, 48 and 72 hours. Fabrication of $\mathrm{C}-$ $\mathrm{Zn}$ batteries was done with thin configurations like sandwiches. Furthermore, voltage was measured with digital multimeter. The results obtained, Open Circuit Voltage (OCV) of $0.72 \mathrm{~V}$ for unfermented electrolytes. Then, the use of fermented electrolytes causes an increase in voltage and current due to decreased $\mathrm{pH}$.
\end{abstract}

Keywords: Batteries, Electrolytes, Fermentation, Noni (Morinda Citrifolia L.)

\begin{abstract}
Abstrak
Baterai $\mathrm{C}-\mathrm{Zn}$ adalah baterai komersial yang banyak digunakan karena mudah dibawa, murah, dan mudah didapat. Namun, hal yang serius adalah masalah limbah baterai yang tidak hanya menyebabkan polusi tetapi juga membahayakan sumber daya alam karena mengandung logam berat $(\mathrm{Mn})$ dan elektrolit korosif. Mengkudu (Morinda Citrifolia L.) adalah buah dengan komponen utama vitamin C (asam askorbat) sebagai antioksidan. Komponen asam ini adalah dasar untuk pemanfaatan lebih lanjut sebagai aplikasi elektrolit ramah lingkungan. Buah mengkudu difermentasi dengan 2 variasi waktu, 48 dan 72 jam. Pembuatan baterai C-Zn dilakukan dengan konfigurasi tipis seperti sandwich. Selanjutnya, tegangan diukur dengan multimeter digital. Hasil yang didapat, Open Circuit Voltage $(\mathrm{OCV})$ sebesar $0,72 \mathrm{~V}$ untuk elektrolit yang tidak difermentasi. Kemudian, penggunaan elektrolit yang sudah difermentasi menyebabkan kenaikan tegangan dan arus karena menurunnya $\mathrm{pH}$.
\end{abstract}

Kata kunci: Baterai, Elektrolit, Fermentasi, Mengkudu (Morinda Citrifolia L.)

\section{INTRODUCTION}

So far, household energy that was needs for electronic equipment, had been replaced with C-Zn batteries (Akbar et al., 2017; Jayashantha et al., 2012). The existence of a battery was easily considered to use the device because of its easy to carry, inexpensive, and easy to obtain (Zloczewska and Niedziolka, 2013). Battery C-Zn is a dry cell that cannot be refilled, it has a carbon component as an auxiliary electrode for the reduction process on $\mathrm{MnO}_{2}$ paste in $\mathrm{NH}_{4} \mathrm{Cl}$, which $\mathrm{NH}_{4} \mathrm{Cl}$ as an electrolyte. However, the 
serious problem is about of its waste which not only caused the pollution, but also natural damage due to corrosive electrolytes and heavy metals (Rochliadi et al., 2015; Akbar et al., 2018). People was still confused in terms of ways to dispose of batteries that are no longer used to be safer. If the battery waste was not recycled or removed, the heavy metals $\mathrm{Mn}$ and substances can pollute the air and soil, which eventually become harmful to the human body. This is a insignificant problem, which if it was not responded correctly and quickly it will be a very serious environmental problem. Therefore, it needs a new innovation to use other electrolytes that are more environmentally friendly, sourced from natural ingredients, so that they can be implemented in $\mathrm{C}-\mathrm{Zn}$ batteries to meet people's needs.

From various studies that have been developed, the several fruits such as oranges, pineapples, apples, coconut water, mangoes, starfruit and other fruits can produce electrical energy (Donaldson, 2018). In this case, the citric acid $\left(\mathrm{C}_{6} \mathrm{H}_{8} \mathrm{O}_{7}\right)$, the natural ingredients, commonly found in fruits. The acidity of a material can affect its electrical conductivity (Fitriani, 2013). In electrolyte conductors, electrons can be accessed by ions, then the component can produce ions include acids, bases and salts (Fadilah and Rahmawati, 2015). The more acidic of electrolytes cause the higher concentration of hydrogen ions so the greater flowing electric current from the anode to cathode. Utilization of lime, local citrus, and orange solutions for electrolite for battery has been done using copper and zinc plates as connecting media (Purnomo, 2010). The data obtained from experiment, can be concluded there is the effect of the acidity of citrus fruit on the strength of the electric current, in this case the more acidic the solution increased the electric current, vice versa, the greater of $\mathrm{pH}$ value, so the smaller electric current. Furthermore, a similar study using citrus fruits with a 250 $\mathrm{mL}$ of on $\mathrm{Cu}-\mathrm{Zn}$ electrodes produced a strong current at $0.45 \mathrm{~mA}$ (Jauharah, 2013). Then, other research on the use of mangoes based on $\mathrm{Cu}-\mathrm{Zn}$ electrodes can also produce electricity voltage up to 118 $\mathrm{mV}$ with measurements using only a multimeter without the aid of a tool (Kuswandi et al., 2011).

Noni (Morinda citrifolia L.) or keumeudee (in Acehnese) has long been used as food ingredients as well as medication. Traditionally, the Acehnese people use this fruit as food in the form of vegetables and salad. The leaves are also useful, usually as one of the nicah ingredients that often appears as a mandatory iftar menu. Therefore, in Aceh Noni is often planted near the house. The important chemical content of noni juice is fatty acids which include: caprylic acid, caproic acid, stearic acid, palmitic acid, and oleic acid, as well as different short chain fatty acids which are stinging (Pratiwa et al., 2015). Furthermore, other nutrients contained in noni fruit are vitamin $\mathrm{C}$ (ascorbic acid) as an antioxidant protein, and mineral (Se) (Assi et al., 2017). Therefore, the acid content in Noni fruit is quite potential to be used as electrolyte on battery.

Through this article, the team studied use of Noni fruit as an electrolyte in C-Zn batteries based on the acid content in it, as well as battery performance based on the length of time the noni fruit fermented. We hope to produce environmentally friendly batteries, so that it becomes one of the 
solutions to overcome the problem of electricity energy production which has contributed greatly to greenhouse gas emissions.

\section{METHOD}

\section{Materials}

The tools used include distillation devices, glass equipment in the laboratory, digital multimeters, crocodile clip cables, hacksaw, pH meters, LED lights (Light Emitting Diode), filters, knives, plastic wraping, and drops pipettes. Furthermore, the material used in this study was noni fruit, Carbon (C) in the form of stickers obtained from Kingbali New Material (Huizhou China), Zinc (Zn), filter paper, and $96 \%$ ethanol.

\section{Noni Fruit Extraction}

Noni fruit was taken from a healthy tree without disease, then the fruit was selected which is quite mature and still fresh. The noni fruit extract made in two type with fermentation and non fermentation. The fermentation was carried out without the use of bacteria, the fruit was left to rot in 2 times, 48 hours and 72 hours. Then the noni fruit was cut into small pieces, then dried in the sun with a shade of black cloth, until the pieces of fruit are completely dry. Black cloth was placed to prevent the degradation of chemical components in the noni fruit due to direct contact with sunlight.

Then the dried noni fruit pieces was blended into powder, $\pm 500 \mathrm{~g}$ of Noni fruit powder was put into a reagent bottle and macerated using ethanol $96 \%$ solvent with a volume ratio between powder and solvent that was $1: 3$. Soaking is done for 6 hours while stirring occasionally, then let stand for 18 hours after that filtered using cotton and gauze, followed by filter paper.

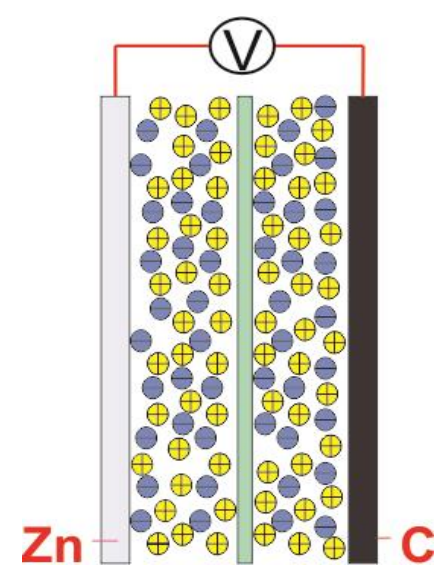

Figure 1. C-Zn battery with Noni extract electrolyte

The pulp obtained was macerated until the filtrate results close to the ethanol solvent color, this process was done until a clear soaking result obtained. After the maceration process, the noni fruit extract solution was evaporated using distillation at a temperature ranging from $100-150^{\circ} \mathrm{C}$, after distillation, the solution was placed in a water bath be aerated to evaporated the remaining solvents contained in Noni fruit extract (Assi et al., 2017).

\section{C-Zn Battery Fabrication}

The C-Zn battery was arranged thinly in sandwich form with $2 \times 2 \mathrm{~cm}$ electrode contact area, the $\mathrm{Zn}$ plates and $\mathrm{C}$ sheet are cut $5 \times 2 \mathrm{~cm}$, the filter paper is slightly wider than $\mathrm{Zn}$ and $\mathrm{C}$ to avoid direct contact between $\mathrm{Zn}$ and $\mathrm{C}$. Previously, noni extract was dripped onto filter paper and made slightly moist. The prototype was connected with a digital multimeter to determine the voltage and the current produced. The array of tools and microscopic illustrations of the working principle of batteries was presented in Figure 1. Battery performance 
was also carried out by applying a prototype to LED lights.

\section{RESULTS AND DISCUSSION Noni Fruit Extraction Process}

Noni (Morinda Citrifolia L.) fruit extract was obtained by maceration (immersion) sample (Figure 2). First, the noni fruit was cut into small pieces and then dried under the sun which above it is given a cover in the form of black cloth so that the process of absorption of heat is perfect, then there is no damage to the chemical components in the fruit. The drying process was done 2-3 days to get fruits that are completely dry. Next, the pieces of noni fruit was crushed until smooth using a blender. The noni fruit powder obtained was put into a container and macerated using ethanol $96 \%$ solvent with a volume ratio between powder and solvent 1: 3 , approximately. Soaking was done at 6 hours while stirring occasionally, then left to stand for 18 hours after filtering using black cloth and filter. The remaining pulp was macerated until the macerated filtrate results close to the color of the ethanol solvent, this was done until a clear soaking result obtained.

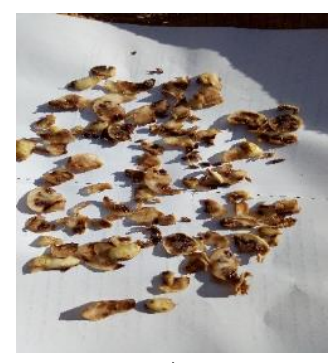

a)

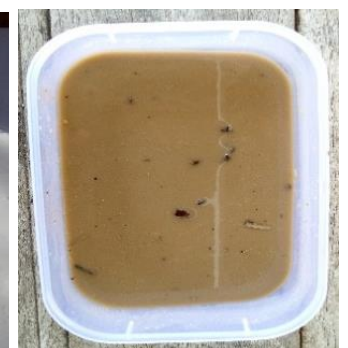

b)
Figure 2. The process of a) drying noni fruit $b$ ) maceration the noni fruit

After the maceration process, the noni fruit extract solution was evaporated using distillation at a temperature ranging from $100^{\circ} \mathrm{C}$ (above the boiling point of ethanol). Taking the boiling temperature is not too high, in this case the fear of damage to the chemical components in Noni fruit extract. After distillation, the solution was placed into a water bath to be aerated so that evaporates the remainder of solvent. The results of extracting Noni (Morinda Citrifolia L.) fruit obtained a brown solution suspension. Furthermore, the same process was carried out for the extraction of noni fruit which has been fermented in 2 and 3 days.

\section{pH of Noni Fruit Extract}

The $\mathrm{pH}$ of extract was measured to determine the difference in acidity between non-fermented noni fruit extract and noni fermented fruit extract. This process was done by dipping the $\mathrm{pH}$ test paper into noni fruit extract (Figure 3). This process is carried out for up to 1 minute and then lifted and matched with the $\mathrm{pH}$ color indicated on the $\mathrm{pH}$ test paper box. The results obtained from the three noni extracts showed that the non-fermented extract found a $\mathrm{pH}$ of between 4-5 which was carried out several times, noni extract which was fermented for 48 hours found $\mathrm{pH} 3$, and fermented noni extract 72 hour was obtained $\mathrm{pH} 2$.

Regular $\mathrm{pH}$ changes are seen quite clearly in Figure 3 in each variation of the time of fermentation of Noni fruit extract. Along with the length of fermentation time, it appears that the $\mathrm{pH}$ of extract decreases. This can be explained by the formation of acetic acid through alcohol oxidation which was formed by decomposition of carbohydrate components in the noni fruit (Igharo, 2012). It is known that the carbohydrate component found in Noni fruit is a derivative of glucopiranose (Assi et al., 2017). 
$\underset{\text { Carbohydrate }}{\left(\mathrm{CH}_{2} \mathrm{O}\right) n \underset{\text { decomposition }}{\longrightarrow}} \mathrm{H}_{3} \mathrm{C}^{-\mathrm{C}_{-}} \stackrel{\mathrm{CH}_{2}}{\mathrm{\textrm {C }}}+\mathrm{CO}_{2}$

$\mathrm{H}_{3} \mathrm{C}^{-\mathrm{C}_{2}} \stackrel{\mathrm{C}_{2}}{\stackrel{\left[\mathrm{O}_{2} \text { (bacteri) }\right]}{\longrightarrow}} \mathrm{H}_{3} \mathrm{C}^{-\stackrel{\mathrm{I}}{\mathrm{C}}-\mathrm{OH}}$

Scheme 1. The process of carbohydrate fermentation and alcohol oxidation

The decrease of $\mathrm{pH}$ that occurs during fermentation was likely formed through further oxidation of alcohol that formed from the fermentation process to carboxylic acid, according to Scheme 1. The carbohydrate component decomposes into alcohol (ethanol) and carbon dioxide gas $\left(\mathrm{CO}_{2}\right)$. Next, primary alcohol oxidized into carboxylic acid to acetic acid form $\left(\mathrm{CH}_{3} \mathrm{COOH}\right)$. Therefore, fermented noni extract donates more $\mathrm{H}^{+}$ions. However, for non-fermented noni extract, the supply of $\mathrm{H}^{+}$ions could be considered to be fully solely derived from ascorbic acid.

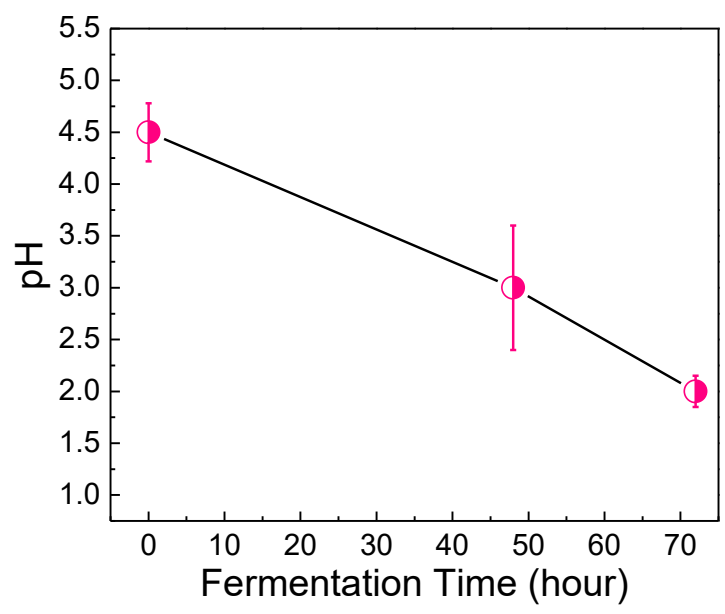

Figure 3. Relationship between fermentation time and $\mathrm{pH}$ produced from noni fruit extract

The duration of fermentation is influenced by factors that directly or indirectly affect the fermentation process. There are many factors that influence fermentation including substrate, temperature, $\mathrm{pH}$, oxygen, and microbes used (Xiao et al., 2017). The extrapolation of the data can be seen in Figure 3 that fermentation with a time of 48 hours produces a $\mathrm{pH} 3$ and fermentation for 72 hours produces a $\mathrm{pH} 2$. In this case it can be seen that the longer the fermentation time, the acetic acid level in noni fruit also increases, if the acid level acetate in noni fruit extract increases, it is certain that $\mathrm{pH}$ will also decrease.

\section{Performance testing of $\mathrm{C}-\mathrm{Zn}$ batteries}

Furthermore, the performance of C$\mathrm{Zn}$ batteries had been measured against $\mathrm{pH}$ variations. It was found that the increase in voltage (V) along with the length of fermentation time (Table 1). This phenomenon shown a fairly good relationship between voltage and current against the $\mathrm{pH}$ of electrolyte. The team also conducted the same experiment by replacing $\mathrm{C}$ electrodes with $\mathrm{Cu}$ (copper) metal. The results obtained was not much different from the $\mathrm{C}$ electrodes with $\mathrm{OCV}$ range between $0.70-0.9 \mathrm{~V}$.

Table 1. Battery C-Zn performance with noni extract

\begin{tabular}{c|c|c}
\hline $\begin{array}{c}\text { Fermentation } \\
\text { Time (Hours) }\end{array}$ & $\begin{array}{c}\text { Voltage } \\
\text { (V) }\end{array}$ & $\begin{array}{c}\text { Current } \\
\text { (A) }\end{array}$ \\
\hline 0 & 0.72 & 2.2 \\
48 & 0.82 & 2.6 \\
72 & 0.87 & 3.2 \\
\hline
\end{tabular}

Therefore, the findings of the voltage produced, are most likely due to the redox reaction between $\mathrm{H}^{+}$ions and $\mathrm{Zn}$ metal. On the other hand, extracts of noni fruit as well as electrolytes also function as substances that are reduced. The position of the cathode becomes an electrode which is only located as a supporting electrode. 
Cathode $: 2 \mathrm{H}^{+}(\mathrm{aq})+2 \mathrm{e}^{-} \rightarrow \mathrm{H}_{2}(\mathrm{~g})$

Anode $: \mathrm{Zn}(\mathrm{s}) \rightarrow \mathrm{Zn}^{2+}(\mathrm{aq})+2 \mathrm{e}^{-}$

cell $\quad: 2 \mathrm{H}^{+}(\mathrm{aq})+\mathrm{Zn}(\mathrm{s}) \rightarrow \mathrm{H}_{2}(\mathrm{~g})+\mathrm{Zn}^{2+}(\mathrm{aq})$

Scheme 2. Redox reactions that occur on C-Zn batteries with noni extract extract electrolytes

Scheme 2 described the possible reactions to this battery system. Based on the cell reactions obtained, there is a correlation that the amount of $\mathrm{Zn}$ that reacts depends on the number of $\mathrm{H}^{+}$. This phenomenon can be explained in two ways. First, based on the reference, known that the potential standard of $\mathrm{Zn}$ was 0.76 $\mathrm{V}$ and $\mathrm{H}^{+}$was $0 \mathrm{~V}$ (Tuurala et al., 2015). Then, it become strong reason with the acquisition voltage from previous measurement of around $0.70-0.9 \mathrm{~V}$ of the C-Zn battery accordance with scheme 2 . Second, it refers to Nernst's law that the reaction equilibrium constant cell is a function of $\left[1 / \mathrm{H}^{+}\right]$, assumes that $\left[\mathrm{Zn}^{2+}\right]$ is constant, so the higher $\mathrm{pH}$, the value of cell voltage will be decrease (Addo et al., 2011).

By extrapolating data into the relationship of fermentation time to voltage and current as shown in Figure 4, the length of fermentation time caused the voltage and current produced to rise. However, there are many other studies that will be task of the team to do in future, related to the threshold limit for how long fermentation time must be taken in order to obtain maximum stress, the effect of differences in electrolyte concentration variations, the effect of contact area between electrodes, and the duration of battery usage performance to charge electricity runs out to be applied on electronic devices. Furthermore, in this study, the ability of $\mathrm{C}-\mathrm{Zn}$ batteries with noni fruit extract electrolytes was tested able to turn on LED lights.

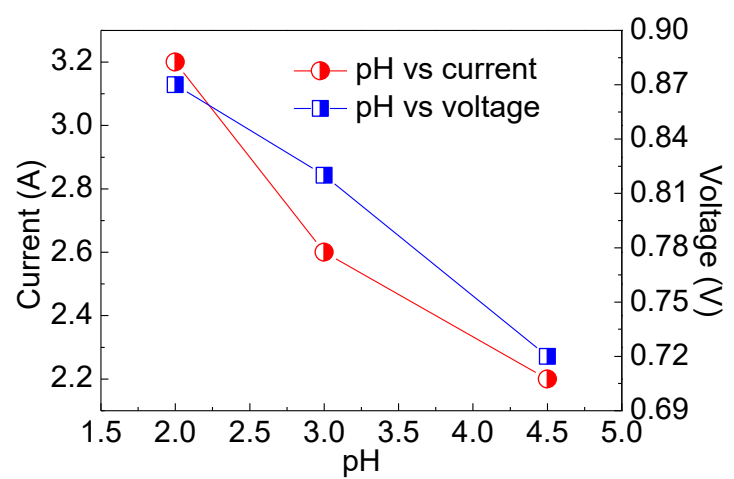

a)

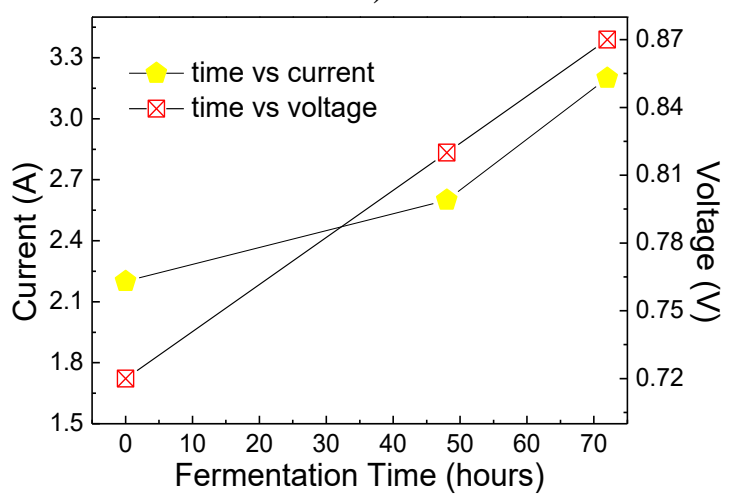

b)

Figure 4. Relationship of OCV (V) and current on $\mathrm{C}-\mathrm{Zn}$ batteries to (a) $\mathrm{pH}$ (b) fermentation time

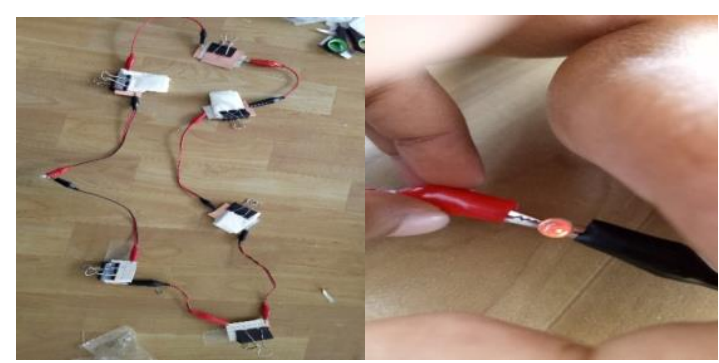

a)

b)

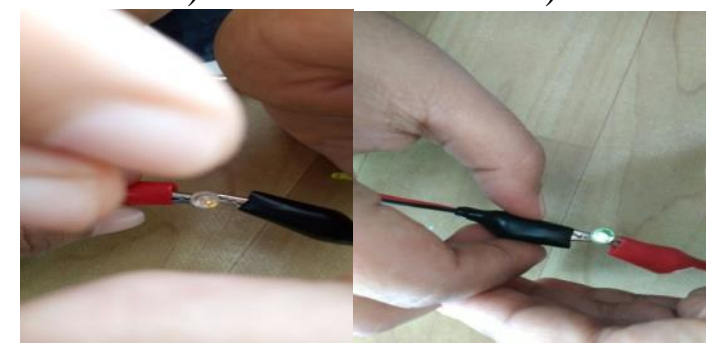

c)

d)

Figure 5. Application of $\mathrm{C}-\mathrm{Zn}$ battery with fruit extract to LED lights (a) series 6 green LED batteries (b) red (c) yellow (d) green 
The provisions of each LED light to be able to live, namely, red and yellow lights require a voltage of $1.7 \mathrm{~V}$ and $2.0 \mathrm{~V}$, green and blue LED lights require a voltage of $2.2 \mathrm{~V}$ and $4.5 \mathrm{~V}$. Therefore, one series of C-Zn batteries was not enough to turn on one LED (minimum red). Furthermore, to achieve the voltage requirement to turn on the LED lights, and also by considering the battery fabrication that was not tightly closed (there is still a gap beside), the C-Zn battery circuit was made in 6 series as shown in Figure 5.

\section{CONCLUSSION}

Noni fruit extract (Morinda citrifolia $L$.) has the potential to be used as an environmentally friendly electrolyte in the $\mathrm{C}-\mathrm{Zn}$ battery. Without fermentation, the $\mathrm{C}-$ Zn battery shown a OCV of $0.72 \mathrm{~V}$, which if arranged 2 series of batteries or a bipolar system at least equals the commercial $\mathrm{C}$ $\mathrm{Zn}$ battery voltage with the $\mathrm{MnO}_{2}$ paste electrolyte in $\mathrm{NH}_{4} \mathrm{Cl}$. The decrease of $\mathrm{pH}$ due to the length of fermentation time as a result of the acetic acid formation. On the other hand, the battery voltage increases with decreasing $\mathrm{pH}$. At low $\mathrm{pH}$, the value of equilibirum constant reaction becomes smaller than at high $\mathrm{pH}$. As a result, the battery's potential value will be higher when $\mathrm{pH}$ is low. In this study obtained OCV $0.82 \mathrm{~V}$ when 2 days fermentation, then OCV $0.87 \mathrm{~V}$ during fermentation for 3 days.

\section{ACKNOWLEDGEMENT}

This work was supported by LPPM Serambi Mekkah University, thanks for its financial support in this research.

\section{REFERENCE}

Addo, P. K., Arechederra, R. L., \& Minteer, S. D. (2011). Towards a rechargeable alcohol biobattery,
Journal of Power Sources, 196(7), 3448-3451.

Akbar, S. A., Mardhiah, A., Saidi, N., \& Lelifajri, L. (2017). Sintesis dan Karakterisasi Polianilina (PANI) dengan Variasi Doping Asam Kuat Menggunakan Metoda Elektrodeposisi, Prosiding Seminar Nasional USM (pp. 557-559). Aceh, Indonesia.

Akbar, S. A., Rochliadi, A., Suendo, V., Saidi, N., Lelifajri., \& Mardhiah, A. (2018). A Raman Spectroscopy Study Of The Polyaniline Electrode On Zn-Polyaniline Rechargeable Batteries, Rasayan J. Chem, 11(4), 1525-1531.

Assi, R. A., Darwis, Y., Abdulbaqi, I. M., Khan, A. A., Vuanghao, L., \& Laghari, M. H. (2017). Morinda citrifolia (Noni): A comprehensive review on its industrial uses, pharmacological activities, and clinical trials, Arabian Journal of Chemistry, 10(5), 691-707.

Donaldson, L. (2018). Stretchable, twistable textile-based biobatteries become a reality, Materials Today, 21(3), 200-201.

Fadilah, S., \& Rahmawati, R. (2015). Pembuatan Biomaterial dari Limbah Kulit Pisang (Musa Paradisiaca). Prosiding Simposium Nasional Inovasi dan Pembelajaran Sains 2015 (SNIPS), Bandung, Indonesia. 45-48.

Fitriani, D. (2013). Pemanfaatan Limbah Kulit Pisang Sebagai Elektrolit Pada Sel Kering. Skripsi. Bandung: UIN Bandung.

Igharo, K. O. (2012). Construction of a primary Dry Cell Battery From Cassava Juice Extracts (The Cassava 
Battery Cell). Journal of Educational and Social Research, 2(8), 18-23.

Jauharah, W. D. (2013). Analisis Kelistrikan yang Dihasilkan Limbah Buah dan Sayur sebagai Energi Alternatif Bio-baterai. Skripsi. Jember: Universitas Jember.

Jayashantha, N., Jayasuriya, K. D., \& Wijesundera, R. P. (2012). Biodegradable Plantain Pith for Galvanic Cells. Proceedings of the Technical Sessions, Srilangka, 9299.

Kuswandi, B., Pisesidharta, E., Budianto, H., Maisara, T., \& Novita, N. (2011). Pemanfaatan Baterai Bekas Sebagai Elektroda Konduktansi Sederhana. Jurnal Ilmu Dasar, 2(1), 34-40.

Pratiwa, C., Diba, F., \& Wahdina. (2015). Bioaktivitas Ekstrak Etanol Buah Mengkudu (Morinda Citrifolia L.) Terhadap Rayap Tanah (Coptotermes Curvignathus Holmgren), Jurnal Hutan Lestari, 3(2), 227-233.

Purnomo, H. (2010). Pengaruh Keasaman Buah Jeruk terhadap Konduktivitas Listrik, orbith, 6(2), 276-281.

Rochliadi, A., Akbar, S. A., \& Suendo, V. (2015). Polyaniline/Zn as secondary battery for electric vehicle base on energy return factor, Proceedings of the Joint International Conference on Electric Vehicular Technology and Industrial, Mechanical, Electrical and Chemical Engineering (ICEVT \& IMECE) (pp. 353-358). Surakarta, Indonesia.

Tuurala, S., Kallio, T., Smolander, M., \& Bergelin, M. (2015). Increasing performance and stability of massmanufacturable biobatteries by ink modification, Sensing and BioSensing Research, 4: 61-69.

Xiao, X., Conghaile, P. O., Leech, D., Ludwig, R., \& Magner, E. (2017). An oxygen-independent and membrane-less

glucose biobattery/supercapacitor hybrid device, Biosensors and Bioelectronics, 98, 421-427.

Zloczewska, A., \& Niedziolka, M. J. (2013). Efficient air-breathing biocathodes for zinc/oxygen batteries, Journal of Power Sources, 228, 104-111. 